\title{
Acidithiobacillus thiooxidans secretome containing a newly described lipoprotein Licanantase enhances chalcopyrite bioleaching rate
}

\author{
Roberto A. Bobadilla Fazzini • Gloria Levican • \\ Pilar Parada
}

Received: 16 September 2009 /Revised: 22 November 2010/Accepted: 5 December 2010 /Published online: 30 December 2010

(C) The Author(s) 2010. This article is published with open access at Springerlink.com

\begin{abstract}
The nature of the mineral-bacteria interphase where electron and mass transfer processes occur is a key element of the bioleaching processes of sulfide minerals. This interphase is composed of proteins, metabolites, and other compounds embedded in extracellular polymeric substances mainly consisting of sugars and lipids (Gehrke et al., Appl Environ Microbiol 64 (7):2743-2747, 1998). On this respect, despite Acidithiobacilli-a ubiquitous bacterial genera in bioleaching processes (Rawlings, Microb Cell Fact 4(1):13, 2005)has long been recognized as secreting bacteria (Jones and Starkey, J Bacteriol 82:788-789, 1961; Schaeffer and Umbreit, J Bacteriol 85:492-493, 1963), few studies have been carried out in order to clarify the nature and the role of the secreted protein component: the secretome. This work characterizes for the first time the sulfur (meta) secretome of Acidithiobacillus thiooxidans strain DSM 17318 in pure and mixed cultures with Acidithiobacillus ferrooxidans DSM 16786, identifying the major component of these secreted fractions as a single lipoprotein named here as Licanantase. Bioleaching assays with the
\end{abstract}

Electronic supplementary material The online version of this article (doi:10.1007/s00253-010-3063-8) contains supplementary material, which is available to authorized users.

R. A. Bobadilla Fazzini $\cdot$ P. Parada $(\bowtie)$

BioSigma 'S.A.',

Loteo Los Libertadores, Lote 106,

Colina, Chile

e-mail: pparada@biosigma.cl

G. Levican

Biology Department, Chemistry and Biology Faculty,

University of Santiago of Chile,

Avda. Libertador Bernardo O’Higgins 3363, Estación Central,

Santiago, Chile addition of Licanantase-enriched concentrated secretome fractions show that this newly found lipoprotein as an active protein additive exerts an increasing effect on chalcopyrite bioleaching rate.

Keywords Chalcopyrite $\cdot$ Bioleaching $\cdot$ Acidithiobacillus secretome $\cdot$ Metasecretome $\cdot$ Licanantase

\section{Introduction}

The use of microorganisms for metal recovery from ores constitutes an industrial process of major interest. In this context, bacterial leaching with the corresponding release of metal ions from insoluble metal sulfides such as copper bioleaching from the refractory chalcopyrite $\left(\mathrm{CuFeS}_{2}\right)$ through biooxidative processes represents an area of active research.

Due to the extreme environmental conditions in bioleaching processes, the predominant bacterial species are extremophiles (particularly acidophilic) able to oxidize iron and sulfur, where proteobacteria belonging to the genera Acidithiobacillus, Acidiphilium, and Leptospirillum are present. Particular attention has been given to the species Acidithiobacillus ferrooxidans since it is the most studied bacterial species among the microorganisms found in industrial bioleaching heaps and dumps together with Acidithiobacillus thiooxidans (Rawlings 2005).

Concerning the role of bacteria in the bioleaching process, contact and non-contact mechanisms have been proposed (Rohwerder et al. 2003). The non-contact mechanism involves planktonic bacteria recycling strong oxidants such as ferric ions. On the other hand, the contact mechanism considers that most cells attach to the sulfide mineral surface forming specialized biofilms and 
that the bioleaching process occurs at the mineralbacteria interphase. In such case, $A$. ferrooxidans and $A$. thiooxidans may act directly catalyzing a straight electron transfer from the metal sulfide to the formation of biomass, or indirectly by means of their ability to oxidize, for example, inorganic sulfur compounds such as elemental sulfur using oxygen as electron acceptor, assisting the solubilization of metal sulfides present in the mineral surface through the elimination of passivation layers that act as diffusion barriers for the oxidative process (Rohwerder et al. 2003). The contact mechanism involves the formation of biofilms where extracellular polymeric substances (EPS) play an essential role in bioleaching bacterial attachment to the mineral surface together with a series of substances that are produced including acid excretion, slime formation, and surfactant and protein secretion among other bacterial products (Sand and Gehrke 2006).

An important role of bioleaching bacteria is to generate an appropriate micro-environment at the mineral-bacteria interphase that allows the occurrence of electron and mass transfer phenomena involved in the bioleaching processes. From this perspective, the production of secreted substances and particularly of EPS has been directly linked to the electrochemical nature of mineral degradation by surface potential measurements, indicating the importance of EPS for metal sulfide dissolution (Gehrke et al. 1998). Moreover, for many years, it has been recognized that Acidithiobacilli and particularly $A$. thiooxidans are able to secrete organic compounds, some initially identified as amino acids and polypeptides (Jones and Starkey 1961) and others as metabolites such as phosphotidylinositol which apparently enhances elemental sulfur oxidation acting as a wetting agent (Schaeffer and Umbreit 1963). However, neither the characterization of the secreted protein fraction nor the determination of its potential role as bioleaching enhancers has been reported. Recently, the fraction of extracellular proteins of $A$. ferrooxidans grown in sulfur and ferrous sulfate was characterized by standard proteomic techniques (2D SDS-PAGE and MALDI-ToF/ToF), indicating the presence of a complex mixture of extracellular proteins in sulfur-grown cultures potentially associated to sulfur solubilization (Zhang et al. 2008) and therefore possibly related to the bioleaching processes of sulfide minerals.

In this study, based on recent proteomic studies performed at BioSigma S.A. of the secreted protein fraction (secretome) of $A$. thiooxidans DSM 17318 pure cultures and mixtures with $A$. ferrooxidans DSM 16786 grown in elemental sulfur, we report here the identification of the major secreted protein component being a lipoprotein named here as Licanantase that is able to increase the bioleaching rate of chalcopyrite.

\section{Materials and methods}

Strains and culture conditions

A. ferrooxidans DSM 16786 and A. thiooxidans DSM 17318 (all strains patented by BioSigma S.A. in their use for bioleaching purposes, patent registration no. CL 44546 and patent application no. CL 2101-2005) were pre-grown at $30^{\circ} \mathrm{C}$ with shaking $(200 \mathrm{rpm})$ in basal $9 \mathrm{~K}$ medium $\left(990 \mathrm{mg} / \mathrm{L}\left(\mathrm{NH}_{4}\right)_{2} \mathrm{SO}_{4}\right.$, $145 \mathrm{mg} / \mathrm{L} \mathrm{NaH}{ }_{2} \mathrm{PO}_{4} \cdot \mathrm{H}_{2} \mathrm{O}, 52 \mathrm{mg} / \mathrm{L} \quad \mathrm{KH}_{2} \mathrm{PO}_{4}, 100 \mathrm{mg} / \mathrm{L}$ $\mathrm{MgSO}_{4} \cdot 7 \mathrm{H}_{2} \mathrm{O}$, and $21 \mathrm{mg} / \mathrm{L} \mathrm{CaCl}_{2}$ ), adjusted to $\mathrm{pH} 1.6$ and supplemented with sulfur $1 \% \mathrm{w} / \mathrm{v}$. Bacteria were inoculated at $1 \% v / v$ with the same conditions as the grown pre-cultures and harvested at the late exponential phase (7-8 days).

Bacterial enumeration

Cell number was determined by chamber counting using a microscope (Thoma Chamber, depth $0.010 \mathrm{~mm}$ ). Strain proportion was determined by specific Q-PCR determination of purified genomic DNA extracted by the phenol/chloroform/isopropyl alcohol method with primers directed against a conserved 16S ribosomal DNA (rDNA) gene region for total bacteria (forward 5'-GTGCCAGCMGCCGCGGTAA3', reverse 5'-CCGTCAATTCCTTTGAGTTT-3'), rusticyanin gene rusB for $A$. ferrooxidans DSM 16786 (forward 5'-GGACACCACCTGGAAAAC-3', reverse 5'TCCCTTGTTGGTGTTGATG-3'), and 16S rDNA gene for A. thiooxidans DSM 17318 (forward 5'-TAATATCGCCTGCTGTTGAC-3', reverse 5'-TTTCACGACAGACCTAATG-3'), all patented by Biosigma S.A. for their commercial use for the identification and quantification of biomining microorganisms (patent registration no. CL 46739 and patent application no. CL 0660-2007).

Concentration of secreted complex protein mixtures (secretome) and subfraction enriched in Licanantase

One to $5 \mathrm{~L}$ of late exponential culture was centrifuged twice at $5,000 \times g$ for $15 \mathrm{~min}$ at $4^{\circ} \mathrm{C}$ in order to separate solids. The culture supernatant was filtered with $0.2-\mu \mathrm{m}$ nitrocellulosedisposable filters to remove any remaining solid and/or cell debris, followed by ultrafiltration in a membrane of $3 \mathrm{kDa}$ (Amicon ${ }^{\circledR}$ Ultra-15, 3 MWCO, Millipore) by centrifugation steps at $6,000 \times \mathrm{g}$ for $30 \mathrm{~min}$ at $4^{\circ} \mathrm{C}$, reducing the volume down to $0.2-1 \mathrm{~L}$ ( $5 \times$ concentration) for bioleaching assays or to $1-5 \mathrm{~mL}(1,000 \times$ concentration) for proteomic analysis. In order to obtain different secretome subfractions, the filtrate was passed through an ultrafiltration membrane of $30 \mathrm{kDa}$ (Amicon ${ }^{\circledR}$ Ultra-15, 30 MWCO, Millipore), obtaining a retained subfraction of $>30 \mathrm{kDa}$ impoverished on Licanantase and an ultrafiltrated subfraction of $<30 \mathrm{kDa}$ enriched in Licanantase. 


\section{2-Keto-3-deoxyoctonate assay}

Determination of the integrity of the outer membrane during the concentration of the secretome was performed by determination of lypopolysaccharide conducted by assay for 2-keto-3-deoxyoctonate (KDO) as previously described (Lee and Tsai 1999).

First dimension: isoelectrofocusing

Analytical determinations were carried out with $50 \mu \mathrm{g}$ of protein mixture determined by Bradford (Bio-Rad protein assay, Bio-Rad), diluted up to $125 \mu \mathrm{L}$ with protein resuspension buffer (7 $\mathrm{M}$ urea, $2 \mathrm{M}$ thiourea, 4\% $w / v$ CHAPS, $20 \mathrm{mM}$ Trizma base), in the presence of ampholytes and under reducing conditions on ReadyStrip IPG strips, $7 \mathrm{~cm}$, pH 3-10 (Bio-Rad). Passive rehydration was carried out for $2 \mathrm{~h}$ at $20^{\circ} \mathrm{C}$ on a focusing tray. Samples were covered with silicon oil to avoid dehydration. Active rehydration was performed at $50 \mathrm{~V}$ for $12 \mathrm{~h}$. Isoelectric focusing was done at a final voltage of $10,000 \mathrm{~V}$ on Protean ${ }^{\circledR}$ IEF cell (Bio-Rad) until reaching $10 \mathrm{kVh}$. Focused samples were stored at $-80^{\circ} \mathrm{C}$ until the second dimension step. Isoelectrofocusing was done at least in duplicate for each sample.

\section{Second dimension: SDS-PAGE}

Focused ReadyStrip IPG strips were equilibrated first in equilibration buffer containing $6 \mathrm{M}$ urea, $0.375 \mathrm{M}$ Trizma base, $\mathrm{pH} 8.6,30 \% \quad v / v$ glycerin, $2 \% \quad w / v$ SDS, and $2 \% w / v$ dithiothreitol (DTT) and later in the same buffer replacing DTT with $2.5 \% \mathrm{w} / v$ iodoacetamide. After equilibration, second dimension separation was performed on $15 \%$ SDS-polyacrylamide $13 \times 9-\mathrm{cm}$ gels with the focused sample embedded in $0.5 \%$ IEF agarose in a Criterion $^{\mathrm{TM}}$ Cell (Bio-Rad) at $150 \mathrm{~V}$ for $1.5 \mathrm{~h}$. The gels were directly stained with ProteoBlue Safe (Coomassie ${ }^{\mathrm{TM}}$ Brilliant Blue G-250, National Diagnostics) overnight and finally de-stained with distilled water. Images of the 2-DE gels were scanned and processed using Z3 v3.0.7 image analysis software (Compugen) for protein differential expression analysis. SDS-PAGE was done at least in duplicate for each sample.
Protein identification

Protein spots from 2D SDS-PAGE were manually cut and processed using In-Gel tryptic digestion kit (Pierce). Tryptic peptides were sent to the Yale Center for Functional Proteomics and Genomics (University of Yale) for LC/MS and MS/MS analysis with an Orbitrap XL mass spectrometer (Thermo Scientific). The generated data were analyzed with Xcalibur software (Thermo Scientific) producing a peptide mass list and identified with SEQUEST and X! tandem search engines against the NCBInr database. Protein identification reported here comes from at least two independent LC-MS/MS analyses.

\section{Bioleaching assays}

Bioleaching assays were done in shake flasks at least in duplicate. Each flask contained $100 \mathrm{~mL}$ of minimal $9 \mathrm{~K}$ media ( $\mathrm{pH} 1.6)$ as described above and supplemented with $1.5 \mathrm{~g} / \mathrm{L}$ of $\mathrm{Fe}(\mathrm{III})$ and $2.5 \mathrm{~g} / \mathrm{L}$ of $\mathrm{Fe}(\mathrm{II})$ with $1 \% \mathrm{w} / \mathrm{v}$ chalcopyrite concentrate $(85.5 \%$ chalcopyrite representing more than $99 \%$ of total $\mathrm{Cu}$ in the assay). Culture media was inoculated with $A$. thiooxidans and $A$. ferrooxidans equally (1.00E $+007 \mathrm{cell} / \mathrm{mL}$ each) and (meta)secretome was added at a final total protein concentration of $10 \mathrm{mg} / \mathrm{L}$. A noninoculated control, a control inoculated but without secretome addition, and an inoculated heat-inactivated secretome with the total secreted protein fraction of $A$. thiooxidans denatured by boiling it for $5 \mathrm{~min}$ at $95^{\circ} \mathrm{C}$ were included. Shake flasks were incubated for 21 days at $30^{\circ} \mathrm{C}$ with agitation, and weekly measurements of cell counts (as described above), Fe(II) by the $o$-phenantroline method (Kolthoff and Sandell 1963), and total iron and $\mathrm{Cu}(\mathrm{II})$ by atomic absorption spectrometry (AAnalyst 400, Perkin Elmer) were performed.

\section{Results}

Culture harvesting at the late exponential phase showed similar total number of cells between pure and mixed cultures and a major proportion of $A$. thiooxidans in the mixed culture as shown in Table 1 . This result indicates that A. thiooxidans has better fitness under the culture con-
Table 1 Species composition at late exponential phase of pure and mixed cultures used in this study

n.d. not detected

\begin{tabular}{llll}
\hline \multirow{2}{*}{\begin{tabular}{l} 
Culture \\
\cline { 2 - 4 }
\end{tabular}} & Q-PCR determinations & \\
\cline { 2 - 4 } & Total bacteria $/ \mathrm{mL}$ & A. ferrooxidans $/ \mathrm{mL}$ & A. thiooxidans $/ \mathrm{mL}$ \\
\hline A. thiooxidans & $2.30 \times 10^{8}$ & n.d. & $6.67 \times 10^{8}$ \\
A. ferrooxidans & $2.70 \times 10^{8}$ & $2.56 \times 10^{8}$ & n.d. \\
A. thiooxidans + A. ferrooxidans & $4.31 \times 10^{8}$ & $1.83 \times 10^{5}$ & $5.46 \times 10^{8}$ \\
\hline
\end{tabular}


ditions used since it overcomes $A$. ferrooxidans growth by three orders of magnitude. Similar results have been reported previously in natural populations of sulfuroxidizing acidophilic bacteria (Knickerbocker et al. 2000), indicating that $A$. thiooxidans has a competitive advantage over $A$. ferrooxidans under current culture conditions.

The amount of total protein secreted in both cultures was determined in the range of $2 \mathrm{mg} / \mathrm{L}$ for cultures with A. thiooxidans. This can be considered a low amount compared to previous reports on Bacillus sp. $(200 \mathrm{mg} / \mathrm{L})$ (Chu et al. 2000) but closer to the reported protein secretion of the biomining microorganism Paenibacillus polymyxa $(20 \mathrm{mg} / \mathrm{L})$ (Patra and Natarajan 2006). No protein secretion was detected in the pure culture of $A$. ferrooxidans using the protocols described here, indicating that no cell lysis or protein leakage could be associated to the observed proteins due to the treatment used. Moreover, KDO assay showed outer membrane integrity during secretome concentration (data not shown). This result is in contrast to the one published by Zhang et al. (2008) where a complex mixture is reported. However, it is important to highlight that the procedures for extracellular protein isolation differ significantly since these authors partially purify the washing solution coming out of an acid incubation at $60^{\circ} \mathrm{C}$ of the cell pellet obtained after centrifugation, while our protocol is restricted only to the sterile-filtered supernatant.

The characterization of the sulfur secretome of $A$. thiooxidans DSM 17318 on 2D SDS-PAGE showed protein spots in a wide spectrum of molecular weight and $\mathrm{p} I$, with a high concentration of protein in the low molecular weight and basic range as observed in Fig. 1 (lower right section), indicating that a large amount of the secreted protein is charged under current acidic culture conditions.
Characterization of A. thiooxidans DSM 17318 sulfur secretome

Analysis by LC-MS/MS of the secreted proteins allowed the identification of ten protein spots with statistical significance (Table 2). First, the sulfur secretome of pure $A$. thiooxidans showed the presence of a predominant protein (Fig. 1, protein spot 1) identified as a putative lipoprotein. Reverse genetics done over $A$. thiooxidans DSM 17318 draft genome sequence starting with ab initio sequenced peptides led us to the nucleotide sequence of the gene codifying for a protein with $96 \%$ amino acidic sequence identity to $A$. ferrooxidans ATCC 53993 putative lipoprotein (NCBInr access no. YP_002220838.1|), a new protein called here as Licanantase. Estimation based on a combination of the area and contrast of each protein spot automatically detected on 2D SDSPAGE renders that over $32 \%$ of the total protein secreted by A. thiooxidans DSM 17318 corresponds to Licanantase.

The remaining secreted proteins were selected based on protein abundance and their identifications are listed on Table 2. In general, most proteins showed a signal peptide supporting the possibility of being secreted. However, several identifications gave no signal peptides on their amino acid sequence. A particularly interesting case was the protein spot 9 (Fig. 1) identified as a porin protein with $42.3 \%$ amino acid identity to Omp40 from A. ferrooxidans ATCC 23270. The Omp40 protein has been identified previously in A. ferrooxidans as the major outer membrane protein and associated to phosphate limiting and $\mathrm{pH}$ variation response (Seeger and Jerez 1993; Amaro et al. 1991) and specifically related to bacterial adherence to the hydrophobic surface of sulfur particles as previously reported (Arredondo et al. 1994). Moreover, Omp40 has been recently associated to a new iron-oxidizing supercomplex from $A$. ferrooxidans, being proposed to
Fig. 1 Bidimensional

SDS-PAGE of the sulfur

batch culture secretome of $A$. thiooxidans. Identified proteins are highlighted with arrows and numerated according to: 1 Licanantase lipoprotein; 3 hypothetical protein Lferr_1276; 4 glyceraldehyde-3-phosphate dehydrogenase; 5 protein TolA; 6 pentapeptide repeat-containing protein, IcmE; 7 hypothetical protein Lferr_1859; 8 3isopropylmalate dehydratase, large subunit; 9, 10 phosphateselective porin $\mathrm{O}$ and $\mathrm{P}$

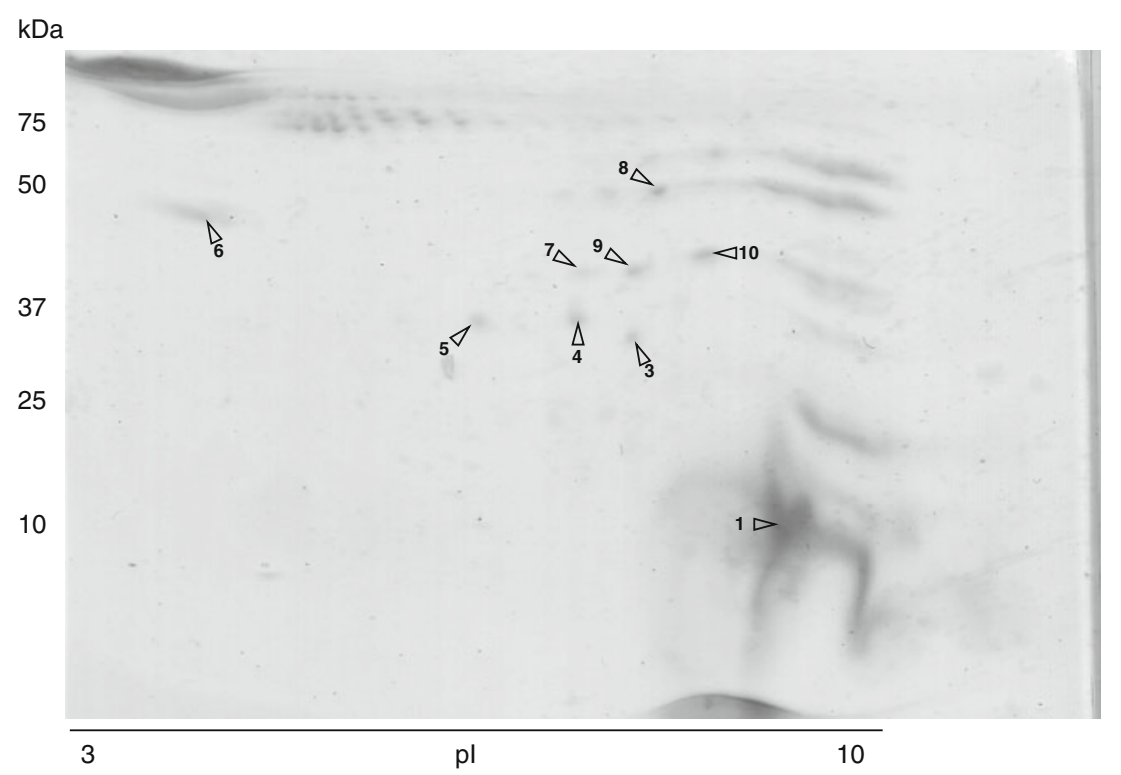









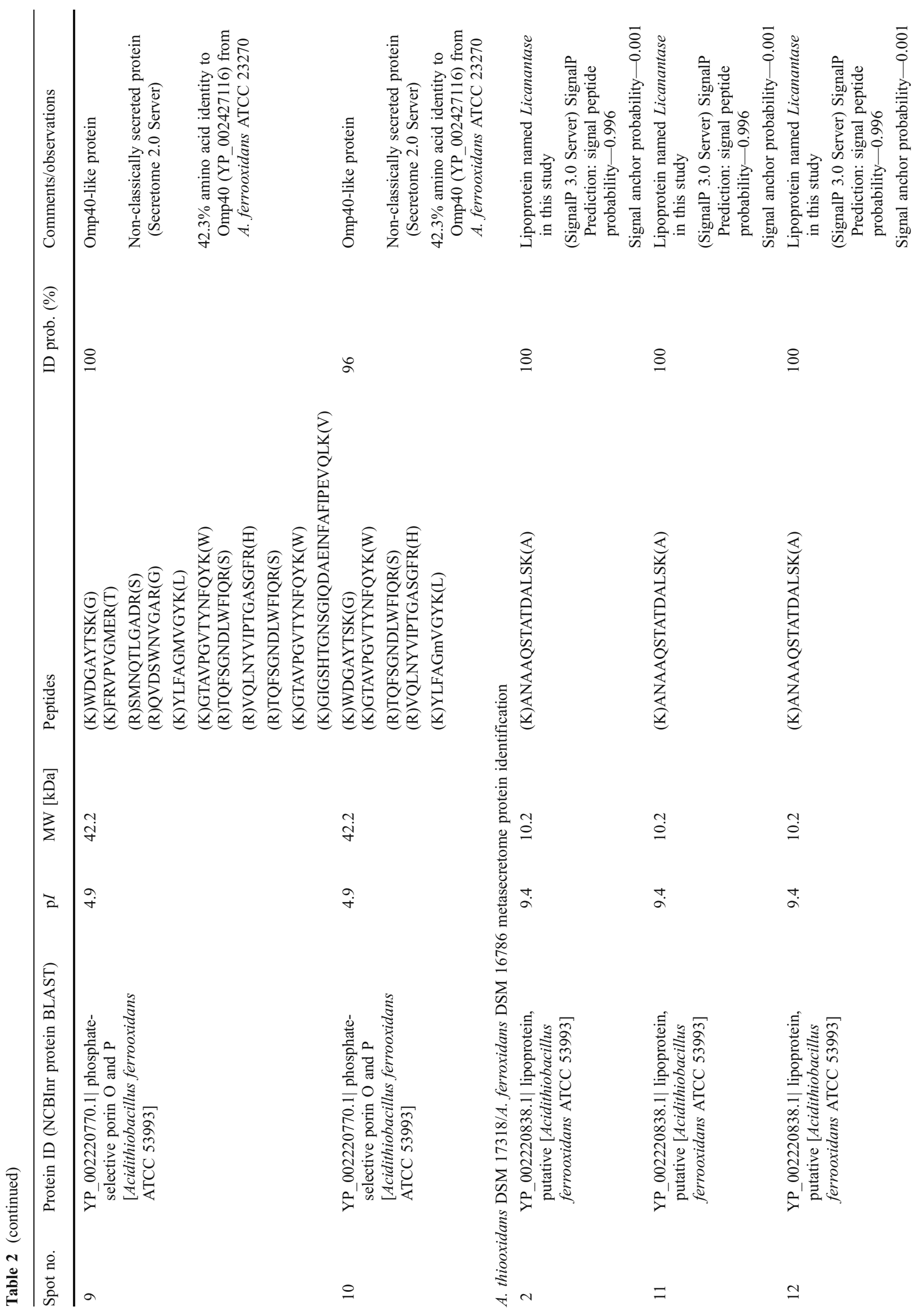




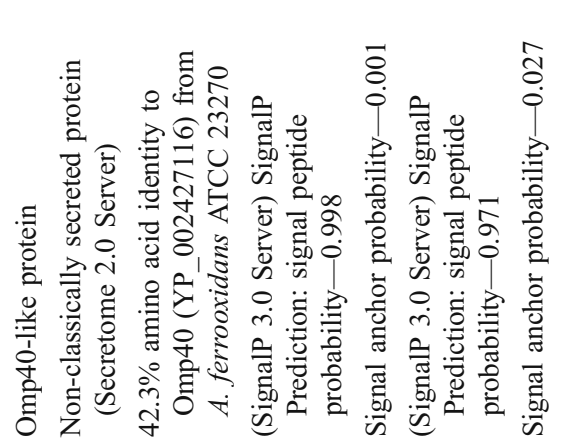

in

0
0
0
0
0
0
0
0
0

$\stackrel{4}{\stackrel{4}{4}}$

$\stackrel{+}{\forall}$

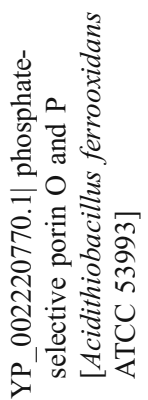

$\underline{2}$

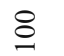

8

ชูo

$\stackrel{0}{6}$

$\stackrel{\infty}{+}$

a.

$\Xi$

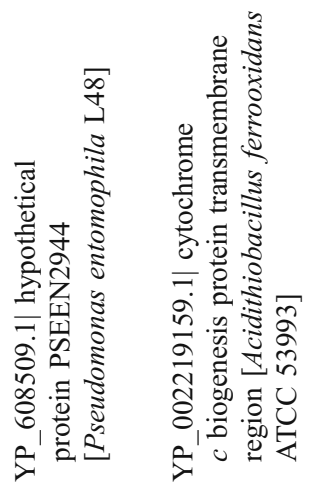

n perform an important function in the bacterial interaction with the substrate, particularly associated to electron transfer pathways (Castelle et al. 2008). However, topology prediction of transmembrane secondary structures in proteins (TMHMM Server v2.0 at http://www.cbs.dtu.dk/services/TMHMM/) based on the amino acid sequence coming from the corresponding coding gene from A thiooxidans DSM 17318 (data not shown) showed no transmembrane helices as described for Omp40 from A. ferrooxidans (Guiliani and Jerez 2000), supporting the hypothesis of secretion of this "Omp40-like" protein. Moreover, analysis with the bioinformatics tool to predict non-classical protein secretion (Secretome Server v2.0 at http://www.cbs.dtu.dk/services/ SecretomeP/) gave a score of 0.88 exceeding the normal threshold of 0.5 and consequently indicating a high probability of being a non-classically secreted protein (Bendtsen et al. 2005). The remaining proteins identified included TolA, a periplasmic protein that couples inner and outer membrane transport complexes, and unexpectedly, glyceraldehyde-3phosphate dehydrogenase and 3-isopropylmalate dehydratase large subunit, related to carbohydrate and amino acid metabolism, respectively. Finally, two hypothetical and a pentapeptide repeat-containing protein $\mathrm{IcmE}$ uncharacterized proteins with no conserved domains and therefore no possible function assignment were found to be present in the secretome of A. thiooxidans.

Presence of Licanantase in the sulfur metasecretome of $A$. thiooxidans/A. ferrooxidans mixed culture

Following the analysis of secreted proteins, a sulfur mixed culture of $A$. thiooxidans DSM 17318 and $A$. ferrooxidans DSM 16786 was grown and harvested at the late exponential phase. It was found that $A$. thiooxidans predominates by three orders of magnitude in the mixed culture, and the secreted protein pattern was similar to the one observed in the pure culture of this sulfur-oxidizing bacteria, with a major protein spot located on the low molecular weight range and basic $\mathrm{p} I$ zone. However, some differences were observed. The metasecretome of the mixture showed up-regulation of high molecular weight protein spots and, interestingly, de novo synthesis of several protein spots as shown in Fig. 2. Identification of protein spot 2 (Fig. 2) gave Licanantase with a $100 \%$ detection probability. Licanantase accounted for more than $19 \%$ of the total protein of the metasecretome, not considering two extra protein spots identified as Licanantase that presented a particular isoelectric point in the bidimensional SDS-PAGE (Fig. 2, spots 11 and 12), indicating the presence of different Licanantase isoforms in the metasecretome possibly due to posttranslational modifications. Also, it cannot be discarded that $A$. ferrooxidans DSM 16786 secretes a similar lipoprotein since the genome of strain ATCC 53993 possesses a codifying sequence for a protein with $96 \%$ amino 
Fig. 2 Bidimensional SDS-PAGE of the sulfur batch culture metasecretome of $A$. thiooxidans/A. ferrooxidans mixed culture. Identified proteins are highlighted with arrows and numerated according to: 2, 11 , and 12 Licanantase lipoprotein; 13 phosphateselective porin $\mathrm{O}$ and $\mathrm{P} ; 14$ hypothetical protein PSEEN2944; 15 cytochrome $c$ biogenesis protein transmembrane region

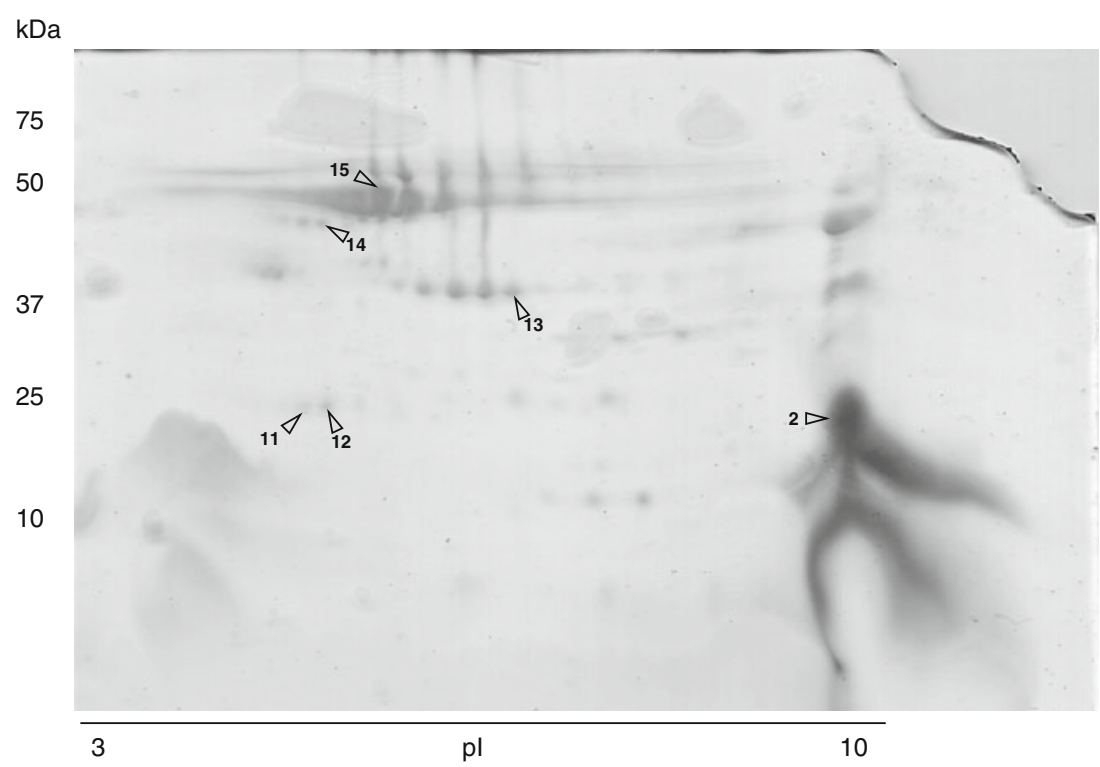

acidic sequence identity. Furthermore, the presence of a putative lipoprotein of the same molecular weight (10.2 kDa) among the extracellular proteins of $A$. ferrooxidans ATCC 23270 grown in sulfur (Zhang et al. 2008) has been reported.

Further identification of selected highly expressed proteins of the metasecretome ratified the presence of the Omp40-like protein observed in the pure culture and an uncharacterized protein identified on public databases as the hypothetical protein PSEEN2944 from Pseudomonas entomophila L48 that presented $14 \%$ amino acidic identity with the hypothetical protein Lferr 0772 from A. ferrooxidans ATCC 53993 (YP_002219229.1|) with no function or conserved domain assigned, but with a predicted signal sequence suggesting that it is a secreted protein. Finally, an eightfold up-regulation of a cytochrome $c$ biogenesis protein was found. This protein assists cytochrome $c$ maturation (Mavridou et al. 2009) and also is reported to facilitate the disulfide bond formation in the folding pathway of many periplasmic and outer membrane proteins by means of electron transport from the cytoplasmic thioredoxin across the inner membrane to specific periplasmic proteins (Rozhkova and Glockshuber 2008). Interestingly, the protein identification matched against $A$. thiooxidans and $A$. ferrooxidans coding sequences $(89 \%$ amino acid identity among sequences), so it is possible that a combination and/or an enhanced protein synthesis is obtained by bacterial interaction in the mixed culture (Fig. 3).

Effect of Licanantase on chalcopyrite bioleaching rate

In order to establish the potential role of the (meta)secretome under bioleaching process conditions, several bioleaching assays were carried out with five times $(5 \times)$ concentrated secreted proteins as additives. As shown on Fig. 4 (left panel), both the sulfur secretome of $A$. thiooxidans and the sulfur metasecretome of $A$. thiooxidans plus $A$. ferrooxidans enhance significantly the copper recovery compared to the controls (between 6\% and 9\% more copper in solution than the controls inoculated without additive and non-inoculated with additive, respectively), pointing out that the (meta)secretome enhances the bioleaching rate of chalcopyrite in a bacterial-mediated manner. The effect was observed from the beginning of the experience and was similar for both the pure and mixed sulfur culture total secreted proteins, and interestingly, it was not related to growth enhancement as shown in Fig. 4 (right panel).

\begin{tabular}{|c|c|c|}
\hline YP_002220838 & 1 & 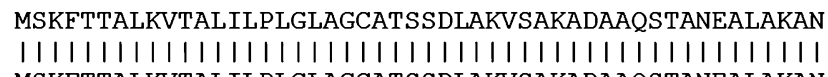 \\
\hline Licanantase & 1 & MSKFTTALKVTALILPLGLAGCATSSDLAKVSAKADAAQSTANEALAKAN \\
\hline YP_002220838 & & $\begin{array}{l}\text { AAQSTATDALSKANAAQSTADQAMSTANAANQKADEANTKVERMFKKSMM } \\
|||||||||||||||||||||||||||||:|||||:|||\cdot||||||||:| \mid\end{array}$ \\
\hline Licanantase & 51 & AAQSTATDALSKANAAQSTADQAMSTANSANQKAEEANEKVERMFKKAMM \\
\hline YP_002220838 & 101 & $\begin{array}{l}\mathrm{K} \\
\mathrm{I}\end{array}$ \\
\hline Licanantase & 101 & 101 \\
\hline
\end{tabular}

Fig. 3 Amino acid sequence alignment of the putative lipoprotein from A. ferrooxidans ATCC 53993 (YP 002220838.1|) and the lipoprotein Licanantase from A. thiooxidans DSM 17318. Amino acid sequence identity of $96 \%$ 


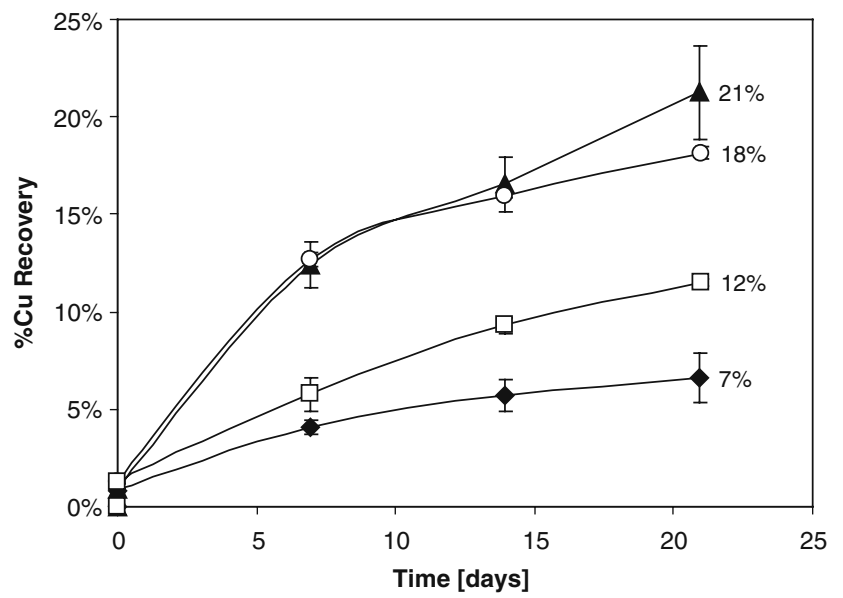

Fig. 4 Chalcopyrite bioleaching assays. Black triangle, $5 \times$ total sulfur secretome of $A$. thiooxidans; empty circle, $5 \times$ total sulfur metasecretome of $A$. thiooxidans/A. ferrooxidans; empty square, control with no

Based on the common protein features observed and identified in $A$. thiooxidans secretome and the mixed culture metasecretome summarized in Table 2 , it can be said that only the proteins identified as Licanantase and Omp40-like were shared and attributable here as common protein elements to exert the observed chalcopyrite bioleaching rate enhancing effect. Therefore to distinguish between these two proteins, a subfractionation of the sulfur secretome of $A$. thiooxidans using a $30-\mathrm{kDa}$ cut-off value was performed by ultrafiltration in order to obtain two enriched subfractions ( $>30 \mathrm{kDa}$ enriched in Omp40-like protein and $<30 \mathrm{kDa}$ enriched in Licananatse). Clearly both subfractions contained protein mixtures, but this was particularly true in the case of the higher molecular weight fraction since several protein identifications were above the cut-off molecular weight value. Surprisingly, only the

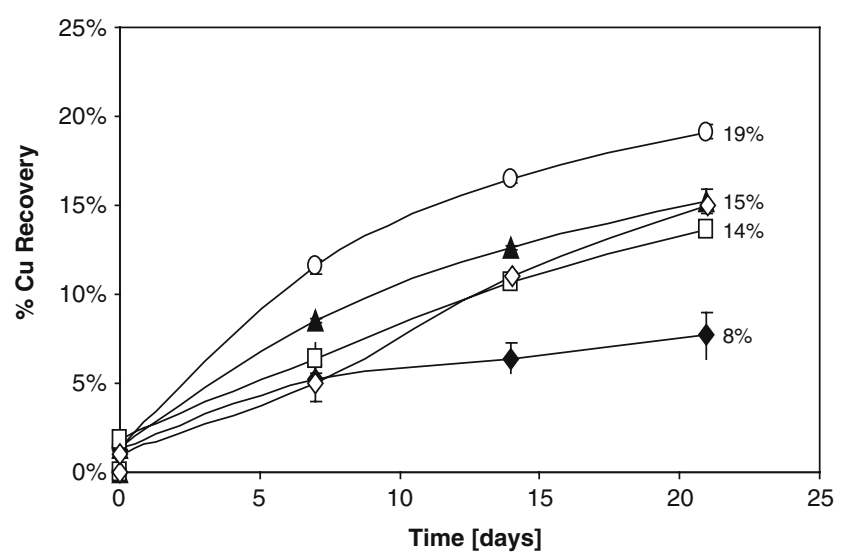

Fig. 5 Chalcopyrite bioleaching assays. Filled triangle, $5 \times>30 \mathrm{kDa}$ subfraction of the total sulfur secretome of A. thiooxidans; empty circle, $5 \times<30 \mathrm{kDa}$ subfraction of the total sulfur secretome of $A$. thiooxidans; empty diamond, control with the addition of $A$.

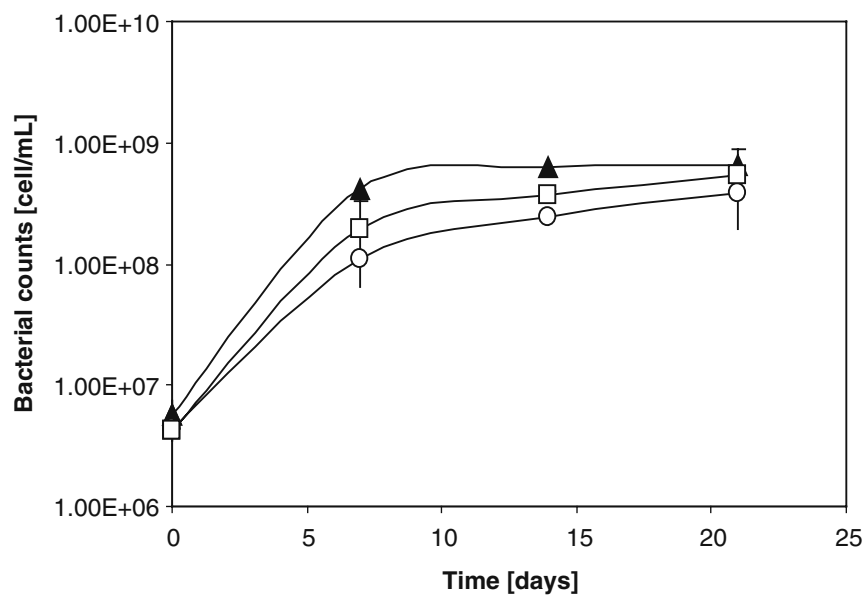

addition of secretome; black diamond, control without inoculum. Left, percent $\mathrm{Cu}$ recovery; right, bacterial growth determinations

subfraction enriched in Licanantase showed a comparable chalcopyrite bioleaching rate enhancing effect compared to the one observed for the total secretome bioleaching under the same assay conditions (Fig. 5, left panel). The sulfur secretome molecular weight fraction higher than $30 \mathrm{kDa}$ as well as the control with heat-inactivated total secretome of A. thiooxidans (boiled for $5 \mathrm{~min}$ at $95^{\circ} \mathrm{C}$ ) showed no effect over the inoculated control without protein additive. Once more, no variations on bacterial counts discard any effect on growth enhancement.

\section{Discussion}

The present study reports for the first time the characteristics of the elemental sulfur secretome of the bioleaching

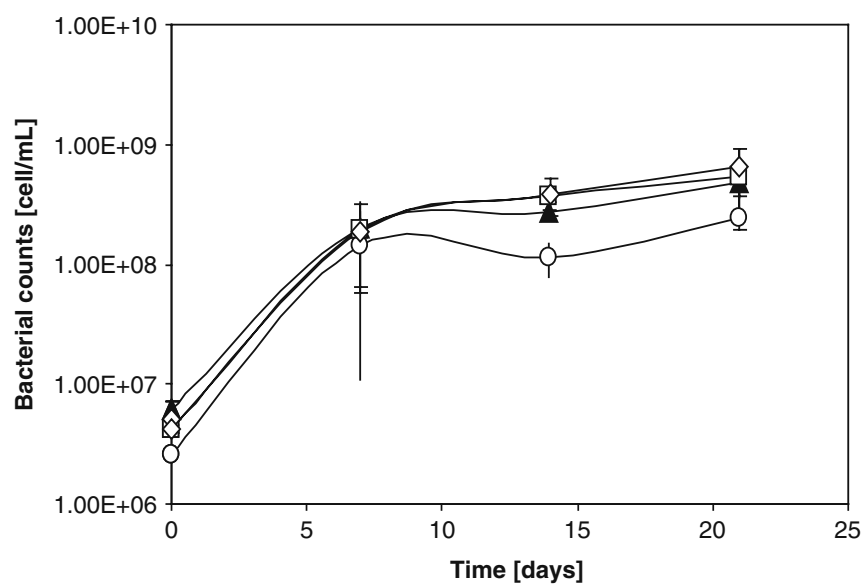

thiooxidans heat-inactivated total secretome; empty square, control with no addition of secretome subfractions; filled diamond, control without inoculum. Left, percent $\mathrm{Cu}$ recovery; right, bacterial growth determinations 
bacterium A. thiooxidans, which shows the presence of protein-mediated processes in bioleaching bacteria and identifies the major secreted fraction as a lipoprotein named here as Licanantase. Moreover, the variations in the protein patterns from pure A. thiooxidans as well as those from mixed A. thiooxidans plus $A$. ferrooxidans cultures grown in sulfur where $A$. thiooxidans is the dominant species show a variation in the protein secretion probably due to the interaction between strains. Protein identification relates the secretion of proteins linked to adhesion and electron transport, which are key aspects in bacterial colonization and oxidation of insoluble substrates. A major question arises from the nature of the proteins identified on the mechanisms of protein secretion. As mentioned in the "Introduction", A. thiooxidans has long been recognized as a secreting strain (Jones and Starkey 1961; Schaeffer and Umbreit 1963), and an outer membrane vesicle "blebbing" has been demonstrated under elemental sulfur growth (Knickerbocker et al. 2000). Outer membrane vesicles are constitutively secreted in Gram-negative bacteria acting as mediators of bacterial endurance (Lee et al. 2008) and are a plausible mechanism of outer membrane and periplasmic protein secretion.

The mechanism by which the observed fivefold enhancement of Licanantase and other (meta)secreted proteins on the bioleaching rate of chalcopyrite is not yet understood and will be continuously the focus of our research group. The newly described lipoprotein Licanantase is the major protein component of the active protein additive that exerts this effect on bioleaching. Certainly, further Licanantase purification and characterization is required in order to establish its role in bioleaching, a task that is currently being developed at our laboratory.

Acknowledgment This work was supported by BioSigma 'S.A.'. The authors thank the company for authorizing the submission of the manuscript for publication.

Open Access This article is distributed under the terms of the Creative Commons Attribution Noncommercial License which permits any noncommercial use, distribution, and reproduction in any medium, provided the original author(s) and source are credited.

\section{References}

Amaro AM, Chamorro D, Seeger M, Arredondo R, Peirano I, Jerez CA (1991) Effect of external $\mathrm{pH}$ perturbations on in vivo protein synthesis by the acidophilic bacterium Thiobacillus ferrooxidans. J Bacteriol 173(2):910-915

Arredondo R, Garcia A, Jerez CA (1994) Partial removal of lipopolysaccharide from Thiobacillus ferrooxidans affects its adhesion to solids. Appl Env Microbiol 66(6):2846-2851
Bendtsen JD, Kiemer L, Fausbøll A, Brunak S (2005) Non-classical protein secretion in bacteria. BMC Microbiol 5:58

Castelle C, Guiral M, Malarte G, Ledgham F, Leroy G, Brugna M, Giudici-Orticoni MT (2008) A new iron-oxidizing/O2-reducing supercomplex spanning both inner and outer membranes, isolated from the extreme acidophile Acidithiobacillus ferrooxidans. J Biol Chem 283(38):25803-25811

Chu PW, Yap MN, Wu CY, Huang CM, Pan FM, Tseng MJ, Chen ST (2000) A proteomic analysis of secreted proteins from xylaninduced Bacillus sp. strain K-1. Electrophoresis 21:1740-1745

Gehrke T, Telegdi J, Thierry D, Sand W (1998) Importance of extracellular polymeric substances from Thiobacillus ferrooxidans for bioleaching. Appl Environ Microbiol 64(7):2743-2747

Guiliani N, Jerez CA (2000) Molecular cloning, sequencing, and expression of omp-40, the gene coding for the major outer membrane protein from the acidophilic bacterium Thiobacillus ferrooxidans. Appl Environ Microbiol 66(6):2318-2324

Jones GE, Starkey RL (1961) Surface-active substances produced by Thiobacillus thiooxidans. J Bacteriol 82:788-789

Knickerbocker C, Nordstrom DK, Southam G (2000) The role of "blebbing" in overcoming the hydrophobic barrier during biooxidation of elemental sulfur by Thiobacillus thiooxidans. Chem Geology 169:425-433

Kolthoff JM, Sandell EB (1963) Textbook of quantitative inorganic chemistry. MacMillan, New York

Lee C, Tsai C (1999) Quantification of bacterial lipopolysaccharides by the purpald assay: measuring formaldehyde generated from 2keto-3-deoxyoctonate and heptose at the inner core by periodate oxidation. Anal Biochem 267(1):161-168

Lee EY, Choi DS, Kim KP, Gho YS (2008) Proteomics in gramnegative bacterial outer membrane vesicles. Mass Spectrom Rev 27(6):535-555

Mavridou D, Stevens J, Goddard A, Willis A, Ferguson S, Redfield C (2009) Control of periplasmic interdomain thiol:disulfide exchange in the transmembrane oxidoreductase DsbD. J Biol Chem 284(5):3219-3226

Patra P, Natarajan KA (2006) Surface chemical studies on selective separation of pyrite and galena in the presence of bacterial cells and metabolic products of Paenibacillus polymyxa. J Colloid Int Sci 298:720-729

Rawlings DE (2005) Characteristics and adaptability of iron- and sulfur-oxidizing microorganisms used for the recovery of metals from minerals and their concentrates. Microb Cell Fact $4(1): 13$

Rohwerder T, Gehrke T, Kinzler K, Sand W (2003) Bioleaching review part $\mathrm{A}$ : progress in bioleaching: fundamentals and mechanisms of bacterial metal sulfide oxidation. Appl Microbiol Biotechnol 63(3):239-248

Rozhkova A, Glockshuber R (2008) Thermodynamic aspects of DsbD-mediated electron transport. J Mol Biol 380(5):783-788

Sand W, Gehrke T (2006) Extracellular polymeric substances mediate bioleaching/biocorrosion via interfacial processes involving iron(III) ions and acidophilic bacteria. Res Microbiol 157(1):49-56

Schaeffer WI, Umbreit WW (1963) Phosphotidylinositol as a wetting agent in sulfur oxidation by Thiobacillus thiooxidans. J Bacteriol $85: 492-493$

Seeger M, Jerez CA (1993) Phosphate-starvation induced changes in Thiobacillus ferrooxidans. FEMS Microbiol Lett 108(1):3541

Zhang C, Zhang R, Xia J, Zhang Q, Nie Z (2008) Sulfur activationrelated extracellular proteins of Acidithiobacillus ferrooxidans. Trans Nonferrous Met Soc China 18:1398-1402 